\title{
A Factor Approach to the Study of the Economic Security System of a Municipal Unit
}

\author{
Elena I. Okhrimenko \\ Ural State University of Economics \\ Yekaterinburg, Russia \\ oelenai@yandex.ru
}

\author{
Sergey A. Chernov \\ Ural State University of Economics \\ Yekaterinburg, Russia
}

\begin{abstract}
The paper substantiates the importance of economic security at the municipal level as an important component of the national security system. The analysis of the existing scientific definitions of the concepts of "safety", "economic security", and "economic security of the municipal unit" is presented. With the help of the system method of analysis, indicators of the state of economic security of the municipality are developed and proposed, their essential characteristics are given. From the position of the factor approach, the main problems of municipal units to ensure economic security are considered; ways of their solution are proposed.
\end{abstract}

Keywords-safety; economic security; economic security of municipal unit; system analysis; criteria and indicators of economic security of municipal unit; factor approach to economic security.

\section{INTRODUCTION}

The relevance of the paper is due to the unpredictability and swiftness of changes in the state of the modern world economy, of which the national economic system is an integral part. This reason determines the need for timely and relevant economic decisions at all levels of government. The constant dynamics of external changes leads to the need for internal innovations in the formation of an adaptive system for forecasting, predetermining, and leveling threats to the economic security not only at the federal level, but also at the level of the constituent entities of the Russian Federation, as well as individual municipal units. The revitalization of activities in municipal units (MU) is of importance at the first stage in the development and strengthening of economic security at its next levels - regional, Russian. It should be borne in mind that municipal authorities do not have sufficient independence; therefore, the development of economic independence of municipal units poses new challenges in the field of municipal development management, including the state of economic security. In this regard, ensuring economic security of municipal units has currently unresolved problems of achieving its optimal level and development [12].

The general welfare of its residents depends on the state of the economic potential of the municipality, therefore, the basis of the economic security of the municipal unit as a category is, first of all, the interests of the population of the municipality, including: ensuring high quality and constantly improving the living standards of the local communities, efficient use of human and economic potential of the MO territory, the implementation of an independent municipal socioeconomic, investment policy, etc. Closest to society and to each specific person, for the reasons mentioned above, economic security becomes precisely at the municipal level, which allows it to be further evaluated at the macro level - the state level.

\section{METHODS}

To analyze the state of economic security of the municipal unit, identify and assess existing threats, the necessary sets of indicators are used. Moreover, the effectiveness of the measures taken to reduce the impact of threats requires the timely implementation of a set of program-targeted measures. In this regard, the purpose of measuring the state of the economy of the municipal unit using parameters and indicators is the timely identification of factors that impede economic growth in order to prevent crisis situations.

The table below shows the indicators of economic security, evaluated as extreme limiting values, for comparing them with actual data, which will make it possible to predict possible negative consequences for the country's economy.

Failure to comply with the norms of indicators that determine the threshold value of economic security leads to an aggravation of the social and political situation in the country, and the destruction of the economy. So, for example, V.I. Guseva, N.A. Brovko, G.V. Sakharov determine that if the extreme limiting values of the indicators are exceeded, the system begins to lose its ability to dynamically develop and reduce competitiveness in external and domestic markets (see Table).

\section{RESULTS AND DISCUSSION}

It should be noted that the concept of "economic security of a municipal unit" is a very complex category, requiring the study of its individual components. At present, science has not yet developed a unified approach to the interpretation of the concept of "economic security". This concept should be considered from different perspectives: personality, society, enterprise/organization, state, etc.

Consideration of the concept of economic security leads, in our opinion, to its understanding as a type of security, legally defined and an integral part of national security. The economic security status of the State characterizes the functioning of the national economy, ensures the sustainability of economic 
economic security means the necessary result - achieving the proper level of security - but not as a process, and therefore it would be more corrects to understand it as "provision of security" [11, p. 46]. It follows from this that economic security is the foundation, the material basis of the national security of the country as a whole.

A municipal unit - the territory within which local government (LG) is implemented - serves as one of the foundations of the constitutional system of Russia. LG is recognized by the Constitution of the Russian Federation and is guaranteed by Article 12 as an independent activity of the population in resolving issues within its interests under its own responsibility. This indicates the proximity of the municipal government to the population, ensuring at the LG level protection of the interests of citizens living together on the territory of the municipal unit, interacting in the process of economic activity.

At a level close to a person, there is a need to ensure security and, as T.L. Silina, "the need for municipal economic security is a basic, fundamental need, both for the life of an individual, family, and various associations of people, including society and the State" [17, p. 1077].

From the foregoing, it can be determined that the economic security of the municipal unit, in particular, belongs to the foundations that make up national security. The definition of this concept, reflecting its essence, is given by E.B. Dvoryadkina and N.V. Novikova, considering the economic security of the municipal unit as "a set of conditions and factors characterizing the current state of the economy and enterprises, on which the standard of living of the population in this territory depends" [5, p. 84]. The above definitions characterize the conditions and factors of a certain territory that has conditions on which the standard of living of the population subsequently depends. It should be noted that the possibilities for the development of the socioeconomic system of the municipal unit in modern controversial processes of globalization and regionalization are more dependent on the human factor.

The municipal unit is a category of system order with subsystems possessing a "local identity", among which the territory, population, and economy are considered to be the main ones. Subsystems of the municipal unit, subject to wellcoordinated functioning, form a socioeconomic system, the purpose of which is the most complete satisfaction of people's needs, and the system itself is characterized by such systemic features as [5]:

- communicativeness (interaction between the system and the external environment);

- integrity (close interconnection of subsystems and structural elements of the municipal unit, involving coordination of actions and management functions);

- sustainability (the ability of the infrastructure of the municipal unit to function relatively independently to ensure a comfortable life);

- self-organization based on the principles of LG,

manifested in the forms of direct will of the population and static nature of the economic system, is the guarantor of its preservation, but it is manifested in the functioning of the socioeconomic system as a whole, with the timely response of all levels of government to neutralize emerging threats. In this regard, I.G. Napalkova notes that as a state of security, 
governing bodies vested with authority on behalf of the population.

The MU system in the process of functioning is affected by the external environment: it changes and develops under the influence of these effects, but at the same time, it retains the properties of the system - qualitative certainty, adaptability of functioning, and relative stability. And, nevertheless, researchers note that this system is characterized by weak structure, which is considered as uncertainty in the composition of the subsystem and elements of the municipal unit, as well as the relationships between them [6, p. 50].

The development of the municipal unit is considered to be as a category that includes both quantitative and qualitative characteristics, which are commonly referred to: living standards of the population, the level of development of social and industrial infrastructure, competitiveness and investment activity of the municipal unit. Any constituent entity of the Russian Federation, including the municipal unit, which is a part of it, is under the influence of internal and external threats. Analysis of the state of internal factors makes it possible to establish and identify the relationship of the strengths and weaknesses of the entity. Identification of weaknesses allows you to identify development prospects. The combination of the internal factors of the municipal unit serves as the basis due to which socioeconomic relations are developing.

Analysis and assessment of the environmental impacts on the socioeconomic condition of the municipal unit makes it possible to determine the expected positive and negative results of their impact, a number of criteria that affect the development of the MU, and assess its development.

The development of criteria for assessing the functioning of LG organs is a problematic task due to the existing uncertainty of the social results obtained and the costs of achieving them. It should be borne in mind that, as V.K. Senchagov notes:

- along with LG bodies, process management in the municipal unit is also involved in other entities of the economic system;

- the social effect is formed not only by the subjects of management, but, first of all, by the object of management the municipal sector [16, p. 87].

The work of LG bodies is to ensure a high standard of living for the population of the territory of the MU, which, in turn, is ensured with the functioning of the municipal sector of the economy.

According to studies, there can be no only negative or only the positive effects of safety factors [8, p. 39]. Researchers include in a generalized system of factors and conditions for ensuring the economic security of the municipal unit the following:

- a high degree of wear of the main engineering communications, which significantly interferes with the work of LG bodies and complicates the life of the population of the municipal unit. This circumstance is a serious problem for municipalities, because for most engineering communications, the service life is coming to an end or has expired due to their creation back in the Soviet period;

- the increase in the illegal sector of the economy, the corruption of government and business inherently represents the shadow services market, which is closely linked to various social institutions: economic, political, cultural, etc., which should be considered as a systemic threat to economic security.

S.V. Rajevski, in our opinion, identifies such significant factors in assessing the state of economic security:

- political stability, which contributes to the preservation of civil peace and social identity, timely resolution of emerging problems and contradictions with the help of the developed mechanisms and means;

- economic growth - during a period of economic growth or economic instability, the MU system is particularly sensitive to these manifestations;

- the increased dependence of LG bodies on the State, the imperfection of intergovernmental relations - legislatively LG bodies are not a part of the state system, but this does not always correspond to practice: in fact, municipalities are not independent in making decisions on any issues within their competence (conflict of power levels on the basis of dependence of municipal authorities on intergovernmental relations);

- demographic processes: aging, population decline, which is primarily an object of economic security of the municipal unit (as a labor resource) [15, p. 145].

D.V. Dotsenko rightly considers the municipal unit as a system (set) of its main elements: power, market, society, and the economy $[6$, p. 55]. The population and public organizations constitute a society with an emerging local market, where market niches of consumers are formed, which helps to meet the needs of the local population. Commodity and infrastructure sectors, as well as organizations, shape the economy. There is always a demand in the market that economic entities satisfy by selling their products. The authority provides protection to the society, manages economic processes in the municipal unit, has the ability to develop and regulate the market. A developed market contributes to the formation of additional power in the authority [6, p. 56].

In order to determine the state of economic security, a comprehensive simultaneous objective assessment of all identified factors is necessary. The level of maximum security is possible only if all indicators are in the acceptable range and do not tend to threshold values. Therefore, the authorities should use indicators for tactical and strategic regulation of the state of economic security. And if the safety indicators of the municipal unit have reached a critical value, this does not always indicate a complete collapse of the socioeconomic sphere or its parts. First of all, this situation requires the prompt intervention of the governing body to change dangerous trends [9, p. 90].

It is possible to carry out gradation of the state of economic security to identify crisis situations, such as, for 
economic security of the municipal unit helps to create the necessary level of ensuring the economic security of the regions, and, consequently, of the country as a whole.

\section{References}

already requires their consideration in management processes. Nevertheless, this condition is not an indicator of the irreversibility of the deterioration of the state as a whole, but indicates a decrease in the quality of life support areas and, in the absence of measures taken to neutralize them, will lead to their critical state.

\section{CONCLUSION}

Assessment of the state of economic security and crisis situations of a municipal unit is carried out according to generally accepted indicators: industrial, investment, scientific and technical, social, food, financial, demographic security, and suggests the need to determine the security of the rule of law and the labor market. LG authorities are faced with the task of accounting for all components of economic security. LG needs to build an effective as well as flexible management system as a whole.

According to I.I. Ovchinnikov, it is possible to ensure the effectiveness of municipal policy through the interaction of LG bodies and state authorities, which should contribute to solving local issues, as well as implementing state-level tasks:

- creating conditions to ensure the vital interests of the population;

- strengthening the foundations of democracy;

- stabilization in the political system;

- training for the work in municipal authorities;

- carrying out measures for social protection of the population [13, p. 247].

At the level of the municipal unit, protecting the rights and legitimate interests of citizens, including in the economic sphere, is a complex task, the solution of which is possible while providing an integrated, strategic approach.

The analysis of economic security of the municipal unit leads to the understanding that the indicators under study will not be as large as at the state level. Despite this, they do not become less important, moreover, a set of indicators of
[1] Big Soviet encyclopedia. M.: Soviet encyclopedia. 1969-1978.

[2] Vodopyanova N.A., Lyskova N.A., Malyutina T. D., Tkachenko D.D. Economic security of municipal units: monograph / N.A. Vodopyanova, N.A. Lyskova, T.D. Malyutina, D.D. Tkachenko. Volgograd: Publishing house of the Volgograd institute of management - RANEPA branch, 2017. 112 pages.

[3] Guseva V.I., Brovko N.A., Sakharov G. V. "Bases of economic security". Bishkek: KRSU publishing house, 2016. page of 100 pieces.

[4] Distance V.I. Tolovy dictionary: living great Russian language [Text]: In 4 t., T.1. - M, 1981. 467 pages.

[5] Dvoryadkina E.B., Novikova N.V. Economic security [Text]: studies. a grant / E.B. Dvoryadkina, N.V. Novikova - Yekaterinburg: 2010. 177 pages.

[6] Dotsenko, D.V. The strategy of regional economic security $[$ Text] $] /$ Works of a regional competition of scientific projects in the field of the humanities. 2016. No. 10. Pages 45-67.

[7] Kostrov A.V. Etymology and semantiko-legal crossing of the concepts "civil defence" and "national security". Technologies of civil safety, volume 14, 2017, No. 2 (52). Pages 72-84.

[8] Kuzmin, V. D. Anti-recessionary council [Text]//Financial right. 2015. No. 9. Pages $32-41$.

[9] Kutafin, O.E. Municipal right of the Russian Federation [Text]: Textbook//O.E. Kutafin, E.I. Fadeyev. - M.: Юристь, 2016. - 359 pages.

[10] Lapusta M.G., Business / M.G. Lapusta. M.: Infra-M, 2008. 608 pages.

[11] Napalkova, I.G. Economic security: institutional and legal analysis [Text]: Monograph(s). G. Napalkova. - Rostov N / Д: SKNTs VSh, 2006. -278 pages.

[12] About the Strategy of national security of the Russian Federation till 2020 [An electronic resource]: Decree of the Russian President of 12.05.2009 N 537. Access from the legal-reference ConsultantPlus system. Access mode://www.consultant.ru.

[13] Ovchinnikov I.I. Local government in the system of democracy. [Text]://M, 2016. Page 247.

[14] Ojegov, S.I. Explanatory dictionary of Russian [Text] / S.I. Ojegov, N.Yu. Shvedova. M, $1994-544$ pages].

[15] S.V. Otsenk's Rajevski of Social and economic safety of municipal units [Text]//Regional economy: theory and practice. 2016. Pages 143-161.

[16] Senchagov, V.K. O of essence and bases of strategy of economic security of Russia [Text]//economy Questions. 2015. No. 1. Pages 84100.

[17] Silina T.L. Essence of a problem of ensuring municipal economic security//Basic researches. 2014. No. 9-5. Pages 1077-1081. 